\title{
4 Positioned for consensus
}

\author{
Market-based approaches, civil society \\ and the role of the state in Chile's coal \\ phase-out
}

\author{
Paelina DeStephano, Beatriz Hernandez Perez, \\ Claudio Huepe Minoletti, Thomas Klug, and \\ Victoria Plutshack
}

\section{Introduction}

In a carbon-constrained world, coal needs to be phased out quickly and replaced with renewable energy sources (Rogelj et al., 2018). In 2019, Chile's President Sebastian Piñera announced a plan to close all coal-fired power plants by 2040 , beginning with the early retirement of eight plants by 2024 . This is an ambitious coal phase-out target, given that coal accounts for 35\% of the country's electricity generation (CNE, 2020). Although this coal retirement scheme only applies to the four companies that currently own coal-fired generation assets in Chile, pending legislation in Congress aims to expand its reach to all energy companies and expedite the timeline for phase-out to 2025 (Bnamericas, 2020a). As a nation with minimal fossil fuel reserves and high renewable energy potential, Chile appears to be well-positioned for a quick and uncomplicated transition away from coal. However, our research finds that this agreement is far from a foregone conclusion and required decades of regulatory refinement, pressure from civil society and an expansion in the role of the state.

Our case study draws on 26 semi-structured interviews conducted in Santiago or virtually between January and December 2020. Interviewees were selected to achieve a balance of policymakers, societal actors and private economic actors. We analyzed qualitative information from interviews using the AOC (actors, objectives, context) framework by Jakob et al. (2020) covered in Chapter 1.The framework serves as a flexible means of examining the political economy underpinning policy formulation. It contends that policy formation is driven by various actors who have unique objectives and different levels of influence on the policy formation process. Policy outcomes reflect actors' objectives based on relative influence and contextual factors. After coding these interviews for relevant objectives and context, we triangulated the narratives that emerged along with secondary data and follow-up interviews to confirm the narratives we present below.

DOI: $10.4324 / 9781003044543-5$ 
To the best of our knowledge, there is no existing systematic understanding of how domestic and international interests and stakeholders influenced the development of coal phase-out in Chile. Our research adds nuance to the work of Florez-Fernández (2020), who finds Chile's energy transition to be a passive revolution reflecting the maintenance of technocratic power relations. Rather, our research aligns with the findings of Allain and Madariaga (2020), who document how traditional energy objectives have been reenvisioned by typically subordinated actors to garner broad support in favor of decarbonization. Our work also leans on the analysis of Alvial-Palavicino and OpazoBunsterac (2018), who chronicled the development of Energy 2050, Chile's long-term energy plan, and found an emphasis on building legitimacy and consensus between government, industry, academia and NGOs. This chapter largely confirms these findings on the alignment of actors, while focusing specifically within the context of Chile's coal retirement scheme.

This chapter is structured as follows: the "Background" section provides an overview of the historical and political underpinnings of the current energy policy regime.The "Findings/explanatory narratives" section presents the results of the analysis, outlining the actors' objectives that have defined Chile's transition to coal and its coal phase-out: affordability, energy security, improved air quality and decarbonization. Finally, the "Discussion and conclusions" section discusses crosscutting factors that have enabled Chile's transition and draw final conclusions.

\section{Background}

\section{Historical and policy context}

In the 1970 s and 1980s, economists educated at the University of Chicago under Milton Friedman laid the foundation for Chile's economic policy during the authoritarian Pinochet regime (Tecklin et al., 2011). Market-oriented ideology is reflected in the Chilean constitution, which describes the primary role of government as supporting competition in the market (Constitution of the Republic of Chile, 1980). Some credit this ideology for the "Chilean Miracle," a period of economic growth from 1987 to 1998 during which per capita income grew by $88 \%$ (Friedman, 1992). Alongside this economic growth, energy demand grew by over $200 \%$ in the same 11 -year period, while it had grown only slightly more than $60 \%$ in the previous 13 years. This economic growth relied on energy-intensive, extractive industries such as mining, which in 2015 accounted for 20\% of Chile's GDP and 37\% of the nation's electricity use (IEA, 2018; MoE, 2016).

Chile was the first country to enact comprehensive electric sector reform in 1982, unbundling and later privatizing state energy companies and creating separate markets for generation, transmission and distribution. In the 1990s with the reestablishment of democratic rule, the new democratic governments avoided radical economic reforms that could upset Chile's economic stability 
Table 4.1 Key policies in Chile's electricity sector

\begin{tabular}{|c|c|c|}
\hline Electricity market policy & Year enacted & Description \\
\hline $\begin{array}{l}\text { Long-Term Contract } \\
\text { Auction Regulations }\end{array}$ & 2005 & $\begin{array}{l}\text { Ended electricity price setting by } \\
\text { National Commission of Energy and } \\
\text { move to contracts that provide more } \\
\text { price certainty for generators }\end{array}$ \\
\hline $\begin{array}{l}\text { Non-Conventional } \\
\text { Renewable Energy Law } \\
\text { No. } 20.257\end{array}$ & 2008 & $\begin{array}{l}\text { Renewable portfolio standard of } 5 \% \\
\text { between } 2010 \text { and } 2014 \text {, increasing } \\
\text { annually to reach } 10 \% \text { by } 2014 \text {. } \\
\text { Noncompliance was fined } 42 \$ / \mathrm{MWh}\end{array}$ \\
\hline $\begin{array}{l}\text { Non-Conventional } \\
\text { Renewable Energy Law } \\
\text { No. } 20.698\end{array}$ & 2013 & $\begin{array}{l}\text { Renewable portfolio standard of } 12 \% \text { by } \\
2020,18 \% \text { by } 2024 \text { and } 20 \% \text { by } 2025\end{array}$ \\
\hline $\begin{array}{l}\text { Auction Reform } \\
\text { Regulation }\end{array}$ & 2015 & $\begin{array}{l}\text { Created three time blocks, improving } \\
\text { competition for variable energy } \\
\text { resources }\end{array}$ \\
\hline $\begin{array}{l}\text { Transmission Law No. } \\
\quad 20.936\end{array}$ & 2016 & $\begin{array}{l}\text { Created National Electricity Coordinator } \\
\text { (CEN) to serve as independent system } \\
\text { operator. Charged government with } \\
\text { long-term energy planning. Shifts } \\
\text { distribution costs from generators to } \\
\text { consumers. Unified the grid }\end{array}$ \\
\hline
\end{tabular}

Source: Bustos-Salvagno (2019), Bustamante et al. (2016), Bersalli (2019).

or the elite who had mostly supported Pinochet's military regime (Barandiaran, 2016). Although government intervention increased, privatization and free market reforms were upheld (Solimano, 2012). Policymaking processes have largely remained stable, characterized by centralization, technocratic rule and strong executive authority. Key electricity policies are listed in Table 4.1.

\section{Energy generation landscape}

In the late 1990s, the traditionally hydropower-reliant nation expanded its fossil fuel generation (Furnaro, 2019). A severe drought, regulatory missteps and an incomplete energy market spurred an energy crisis in 1998-1999 (Madariaga \& Allain, 2018; Murillo \& Foulon, 2006). The energy deficit reached 7.6\% at the height of the crisis and customers faced rationing and blackouts.

In the aftermath of the drought, natural gas imports from Argentina became increasingly important to Chile's energy mix. However, Argentina restricted natural gas exports to Chile in the early 2000s, prompting another crisis and once again revealing the fragility of Chile's energy sector. When the crisis began, Argentinian natural gas was slated to fuel 35\% of Chile's installed power generation capacity (Chávez-Rodríguez et al., 2017). While the sudden curtailment of gas did not lead to blackouts, the crisis raised energy prices and sent generators scrambling for new energy sources. Chile's share of coal-fired power 
more than doubled over a decade, rising from 18\% in 2006 to $41 \%$ in 2016 (Nasirov et al., 2020).

Despite significant coal reserves in the south, high exploitation costs and poor-quality coal limit Chile's domestic coal production. In 2019, Chile's domestic production of coal accounted for $12 \%$ of its coal supply, and its natural gas production accounted for less than one-quarter (EIA, 2021). Imported coal from Colombia, Australia and the United States has been instrumental in securing Chile's energy supply over the past decade (IEA, 2018).

\section{Findings/explanatory narratives}

Chile's decision to phase out coal-fired power generation is undergirded by decades of context that has helped to shape the objectives of key actors and bring them into alignment. Each of the following narratives describes an objective held by key political and societal actors and how it has contributed to the rise of renewable energy and the subsequent decision to phase out coal.

\section{Affordable electricity and a competitive market}

While cheap electricity is important for Chile's extractive economy, affordability among residential consumers is a key issue. Chile has one of the highest electricity prices in Latin America for residential users. Prices are an important "kitchen table" issue that the government is pressured to address, especially given the nation's energy poverty rate of $15 \%$, defined both as perceptions of poverty or as energy expenditure as a percentage of income (Villalobos et al., 2021). Affordability has become critical in the wake of the social upheaval in 2019 that focused on economic inequality; in the immediate aftermath of the protests, the government canceled a planned $9.2 \%$ rate hike [bn 1, bn 2, bn 3 , bn5, pn1, pn8, pn9, si1, sn4] (Bnamericas, 2019; Global Petrol Prices, 2021). Affordable electricity is a key priority for both residential and commercial consumers, but residential consumers pay more at USD $\$ 0.195 / \mathrm{kWh}$ as opposed to the commercial rate of $\$ 0.147 / \mathrm{kWh}$ (Global Petrol Prices, 2021). In the pursuit of electricity affordability, the Ministry of Energy and Government of Chile (GoC) has supported the introduction of electricity auction reforms to enable greater competition from cheap wind and solar.

\section{The role of competition}

Because the $\mathrm{GoC}$ is committed to market nonintervention, originating from constitutional limitations to state activity, competition emerges as an objective of its own. This is reflected in the role of the government in the electricity sector, where it serves to "develop a model to promote the energy transition based on the market" without the use of subsidies [sn4]. The government sees competitive markets as the means to securing lowering prices and attracting international investment [bn3, bn4, bn5, pn5, pn7, pn8, pn9 sn4]. Hence, the 
Ministry of Energy supported long-term contract (LTC) auctions for the energy sector in 2005, allowing generation companies to compete with one another.

\section{Promoting renewables through legislation}

Despite efforts for LTCs to allow new entrants to compete, renewables still struggled to significantly reshape Chile's carbon-intensive generation profile (Bustos-Salvagno, 2019). Some members of a technical-parliamentary citizen commission for sustainable development believed that high-electricity prices reflected high market concentration and a model that privileged fossil fuel generators (Pacheco, 2018, 88). Renewable energy costs, especially global solar costs, had dropped significantly in recent years, and the electricity regulator expected that renewable technologies would handily outbid competitors and reduce electricity prices [bn4, pn8]. Indeed, although initial technical analyses suggested that utility-scale PV solar would cost approximately $\$ 100$ per MWh by 2020, currently Chile's solar projects are some of the cheapest in the world, with a levelized cost of energy at less than $\$ 30$ per MWh, well below \$77-167 per MWh for coal plants (Bloomberg NEF, 2020; Timilsina, 2020; Tringas, 2011).

Despite these low costs, renewable technologies did not initially win many tenders, because the auction design did not allow for the flexibility that renewables required, and electricity prices remained stubbornly high (FloresFernández, 2020). To address these designs' weaknesses, auctions were reformed in 2015 to shift to three time blocks, increasing flexibility and, thus, competition in the electricity market (Bustos-Salvagno, 2019). These efforts to improve competition led to the number of auction participants increasing from only 1 in 2012 to 84 participants in 2016 (Bersalli, 2019, 9-10). Subsequently, electricity generation prices decreased by $75 \%$ from 2012 to 2017 from around $\$ 130$ to $\$ 30$ per MWh (IEA, 2018, 94).

Likewise, the Transmission Law of 2016 (Law No. 20.936) specifically sought to level the playing field for renewables. By unifying the country's two main grids and transferring transmission costs to consumers, the law enabled the connection of demand centers with regions of high renewable potential (Bustamante et al., 2016). The law also created a tender system for complementary services needed with higher degrees of variable renewable energy (IEA, 2018).

The focus of Chile's government on achieving affordability through competition has resulted in greater penetration of renewables into the market. As of 2019, 21.8\% of installed capacity in Chile was non-conventional renewable energy (NCRE), with 10.7\% solar and 6.7\% wind (Bersalli, 2019). In terms of electricity production, wind and solar produced $0.77 \%$ of Chile's electricity in 2013 and rose to $14.3 \%$ in 2019 (Enerdata, 2020). As renewables are not subsidized, this makes Chile one of the first nations to see renewable energy directly compete with conventional energy sources in price-based auctions (Ellis et al., 2019). 


\section{Energy security}

Affordability and security are closely linked energy objectives in Chile. Together, they form the first pillar of the government's long-term sectoral strategy, Energy 2050, but historically these objectives have been in conflict.The focus on low-cost generation in Chile's regulatory environment created a fragile energy system that did not consistently favor diversification [sn8]. Primary energy sources were disrupted in turn by energy crises, resulting in electricity shortages and price increases that were poorly received by the public (Agostini et al., 2017). The political fallout from these crises motivated the government to take a more active role in balancing affordability and security concerns.

\section{Energy crises}

Chile's two major energy crises increased the political salience of energy policy and expanded the government's functions in this sector. The first month of the 1998-1999 energy crisis saw daily coverage by Chile's two largest newspapers. By May 1999, 24\% of Chileans named the electricity shortages as the main problem facing the country (Murillo \& Foulon, 2006). An inquiry found the government and energy companies at fault, and the president's approval rating dropped as demonstrators took to the streets (Stern, 1999).

The geopolitical nature of the Argentinian natural gas crisis reinforced the importance of developing domestic energy resources for many stakeholders. For societal groups, it showed "that the state had no realistic projection about the challenges of energy policy" [sn8]. The Ministry of Economy saw energy independence as a way to reduce foreign currency expenditures on imported fossil fuels [sn2]. Securing domestic energy supply also promoted economic development, another important political objective [bn2, bn3, bn4, bn5, pn8]. In 2016, the government's approach to energy security included increased fossil fuel extraction, despite a lack of concomitant policies to encourage fossil fuel development (MoE, 2016). However, given Chile's significant renewable energy potential, a focus on energy security supported a shift toward renewables, a link that environmental organizations leveraged in their advocacy [sn8] (Madariaga \& Allain, 2018).

\section{An expanded role for the state}

In the wake of these crises, there was an increasing sense that the government needed to be more proactive in directing energy policy, going beyond the constrained regulatory role described in the section on affordable electricity above. The market, as constructed, had experienced high-profile failures to secure sufficient energy supply, highlighting the need for generation diversification and long-term planning.

The passage of the first NCRE law aimed to increase domestic energy production through a renewable portfolio standard. This first entry into renewable 
energy policymaking reflected an objective of energy security rather than decarbonization, allowing generators to pay a fee in lieu of compliance (Allain \& Madariaga, 2020). Ultimately, the impact of this law on diversifying generation was limited until the auction reforms described in the "Power sector overview" section took place.

High electricity prices stemming from supply shortages risked hampering economic development. In the aftermath of the natural gas crisis, the Ministry of Energy emerged as a key actor in conducting long-term planning to prevent future energy crises (Pacheco, 2018). The Ministry developed a more democratic vision for the energy sector through the Energy 2050 strategy. The participatory planning process for Energy 2050 also represented an unprecedented approach to policymaking in Chile, moving beyond cozy relationships with sectoral stakeholders and engaging with the wider public [sn3, sn8].

However, growth in the renewable energy sector also creates energy security challenges. Energy-intensive and economically important industries, such as mining, are concerned about intermittent resources and shouldering the cost of transmission and storage upgrades [bn1]. Incorporating renewable resources, along with the requisite storage, transmission and flexibility, is one of the sector's central upcoming regulatory challenges [bn2, bn $4, \mathrm{pn} 8$, si1]. The pursuit of energy security catalyzed early clean energy policy, but a broader mix of objectives explains Chile's current decarbonization efforts explored in the following sections.

\section{Air quality}

Chilean energy policy has long revolved around the twin objectives of affordability and energy security, reflecting the main concerns of the government and private sector actors. However, as the influence of civil society increased and the Ministry of Energy became more active in long-term energy planning, the sector rebalanced around a broader array of objectives. Social objectives are increasingly reflected in executive actions, judicial rulings and energy planning. Air pollution has historically been seen as the main environmental challenge by citizens, and protests against coal plants have been instrumental in changing the public perception and economics of coal generation [bn4].

Chile faces notoriously bad air quality with over 8 million inhabitants exposed to air pollutants above statutory limits between 2015 and 2017 (Lizama \& Figueroa Serrano, 2018). Air pollution is largely attributed to woodsmoke, vehicle exhaust, industry and, in some places, coal power plants, magnified by topographical and meteorological conditions (Díaz-Robles et al., 2011). Certain areas with highly concentrated air pollution from coal plants and industry are deemed "sacrifice zones" and inhabitants face elevated risks of cancer and lead poisoning linked to chemicals found in coal ash deposits (Tapia-Gatica et al., 2020). Though industrial air pollution has been trending downwards, spills and 
toxic air pollution events in sacrifice zones gained media coverage, drawing political attention to the human costs of air pollution and creating a strong rhetorical argument against coal plants [bn2, pn6, pn7, pn10, sn5] (Greenpeace, 2021). As one interviewee stated,

When we had the emanations, the toxic effects in Quintero-Puchuncaví, that was something that also awakened, that I believe contributed to the feeling of abuse, right? To the feeling of inequality in our society, of inequities, of lack of environmental justice, of having territories that receive pollution, that receive the waste in an inequitable and unequal way.

[sn7]

\section{Social participation and movements}

Protests against coal power plants brought local concerns about air pollution to the national stage, and the movements turned out thousands of protestors in Santiago, project sites and nationwide. Barrancones, a proposed coal plant sited near ecological preserves, was approved by environmental authorities in 2010. The project developer ultimately decided to cancel the project after then-president Sebastian Piñera, pressured by large protests, requested the project site to be moved (Agostini et al., 2017). Environmentalists and the general public criticized Piñera's action despite generally agreeing with the outcome. Instead of strengthening the institutional framework for stronger environmental protection, Piñera relied on his close ties with the private sector to intervene in the unpopular development [pn5]. Citizens found fault with this process, demanding stronger institutions and structural changes to prevent such projects from being developed in the future and isolate decisions on development from the will of the authorities (Cordero Vega, 2010).

Environmental protests were not confined to coal plants either. In 2011, 80,000 people in Santiago took to the streets to protest against a proposed large hydro project in the southern region of Aysén, HidroAysén (Agostini et al., 2017). Activist networks mobilized protests in cities throughout the county, in one of the largest mass demonstrations in recent history [sn3]. Energy-intensive, extractive industries seen as necessitating the project also drew the ire of protestors [bn1]. Protests have also stalled transmission projects, despite being linked to increasing renewables (Azzopardi, 2018). A 2012 article estimates $\$ 22$ billion of energy investment was suspended at a time when energy demand was growing rapidly (Reuters, 2012).

The second Bachelet administration recognized the need to socially validate the nation's energy strategy through broad participation to mitigate social conflict [sn7] (Alvial-Palavicino \& Opazo-Bunster, 2018). Activists and protestors shuttered energy projects through social movements and helped catalyze the inclusion of more established environmental NGOs in the government's social participation efforts. (Castiglioni \& Kaltwasser, 2016; Ureta, 2017). 
Judicialization and environmental regulations

Environmental organizations also became effective plaintiffs in an increasing number of lawsuits against coal projects. The Chilean Supreme Court revoked permits for Central Castilla, a proposed coal plant in 2012, saying that the project would "harm the constitutional guarantee that one can live in an environment free of pollution" (Reuters, 2012). Other projects were fined or temporarily suspended after local groups sued. In 2015, a plan for the Punta Alcalde coal plant was abandoned after long-fought permit battles and judicial rulings established strict monitoring protocols (Reuters, 2015). The court rulings not only impacted private companies but also extended to the government, ruling that agencies were responsible for coordinating to prevent air pollution and other types of environmental degradation [sn7] (Linazasoro Espinoza, 2020).

Chile's 2010 entry into the OECD and free trade agreements required stricter environmental regulations (Carrasco \& Maillet, 2019; Madariaga, 2019). In 2012, the Ministry of Environment introduced tighter air quality standards, which increased the cost of coal generation. The second Bachelet government also imposed a tax on carbon and local air pollution in 2014, taxing emissions from boilers or turbines exceeding $50 \mathrm{MW}$. While the tax is generally seen as insufficient to significantly reduce emissions, it sent an important political signal to generators [pn1, pn10] (Mardones \& Flores, 2017).

\section{Decarbonization}

Rising awareness of climate change

With the emergence of climate change as an issue of popular interest - driven by domestic concerns and attention around hosting the UN Climate Change Conference, COP25 - decarbonization represents another key objective for the GoC and the Ministry of Energy. The Ministry of Energy has faced limited resistance to the Voluntary Coal Retirement Scheme, largely due to alignment with the first three key objectives: the pursuit of affordable and secure energy brought about changes to the electricity market that supported renewables and judicial rulings in response to civil society made coal-fired power development more challenging and expensive.

In the past, international NGOs in Chile have focused on air quality and environmental degradation. However, recent polling data from 2015 shows that $77 \%$ of Chileans believe that "climate change is a very serious problem," which has reflected an uptick in concern over the impacts of climate change [pn1, pn3, pn5, pn6, pn7, pn9, si1, sn5] (Pew Research, 2015). In more recent polling, Chileans ranked the "environment" as the fourth most important challenge for the country (Ministry of Environment, 2018). The growing public awareness of climate change seems instigated by international efforts, which "took on a little more strength" since COP21 [bn1, sn5]. Chile's role in initially hosting COP25 and the popularity of Greta Thunberg were cited for driving popular 
awareness of the climate crisis [pn1, pn3]. Increasing public engagement with climate issues intensified pressure on the Chilean government to take action.

Increased public concern is mirrored in the activities of the international NGOs, which, along with national organizations like Chile Sustentable, form the core of civil society activism in Chile. In the past, they have focused on the protection of the local environment, like opposing the HidroAysén hydroelectric project, but this has changed more recently as concerns about air quality were leveraged in the lead up to COP25 to criticize Piñera's decarbonization plan [pn5] (Greenpeace, 2019). It is not clear whether the increased emphasis on climate change by NGOs, like the WWF and Greenpeace, reflects popular awareness in Chile or a prioritization of the international objectives of these organizations. Evidence from interviews suggests that WWF Chile's objectives adhere to the agenda of its parent organization but are also largely responsive to Chile's environmental priorities [sn2].

\section{Impact of international pressure}

The GoC has also faced international pressure to decarbonize, namely from its ratification of the Paris Agreement in 2017 and its plan to host COP25 [bn4, pn8, si1, sn4, sn5]. In its Nationally Determined Contribution (NDC), Chile committed to a GHG emission budget not exceeding 123 MtCO2eq by 2030. As of 2020, Chile has deepened this commitment by limiting the budget to 95 MtCO2eq by 2030 (GoC, 2020). In the 2020 update to Chile's NDCs, the GoC identifies coal plants specifically as the main challenge for compliance: "The Energy Sector (related to fossil fuels consumption) is responsible for most GHG emissions nationwide, accounting for $78 \%$ of total emissions in 2016, primarily due to the use of mineral coal for electricity generation and diesel for terrestrial transportation" (GoC, 2020).

In January 2018, an agreement was signed to restrict further construction of coal-fired power plants and complete phase-out by 2050. The incoming center-right Piñera II government established a discussion table ("decarbonization table") comprising all main actors of industry, including owners of coal assets, which reached a voluntary agreement to eliminate all coal generation by 2040 and retire 8 of Chile's 28 coal plants by 2024. This concluded in time for COP25, presenting an opportunity to demonstrate Chile's leadership on climate action at an international climate conference. As the initial host of COP25 (before it was moved to Spain due to social unrest), Chile faced pressure from international NGOs to take bold action on climate issues [pn8, si1]. Chile wanted to be "an example to the world of how things are being done" [si1].

Although the timing of the agreement coincided with the climate talks, the agreement itself represented the objectives of the Ministry of Environment as well as energy companies. At COP23 in 2017, Marcelo Mena, then Minister of Environment, was introduced to the Powering Past Coal Alliance (PPCA), a "coalition of national and sub-national governments, businesses and 
organizations working to advance the transition from unabated coal power generation to clean energy" [sn3] (PPCA, n.d.). Minister Mena wanted Chile to join the alliance, but the group Business Leaders for Climate Action (CLGChile) told Mena that Chile was "not in a position to sign this as a country" [sn3]. Although Minister Mena relented and did not join the PPCA, Mena and the Minister of Energy, Andres Rebolledo, maintained pressure on the "Big Four" energy companies with coal assets to negotiate an alternative [bn4, sn3, sn5]. Eventually, the Big Four reached an agreement with the GoC, and to quote a representative from the Generadoras de Chile (Association of Chilean Power Generators):

When the possibility of working with the government on the issue arose because it was an emerging issue at the global level, there was the Powering Past Coal Alliance. We were not going to be able to do this adequately, so what we did as an association was facilitate an agreement between the Ministry of Energy and [the Ministry of the] Environment and us and the four companies to constitute a working table.

The plan for voluntary coal closures represented the bold action that the GoC was looking for, while accommodating a slower transition to placate generator's concerns.

\section{Voluntary Coal Retirement Scheme}

The plan required energy companies to agree that (1) there would be no new development of coal-fired power plants, (2) there would be a retirement of all coal-fired power plants, given necessary conditions and (3) there would be a working group "to define the social, economic and environmental conditions so that later the companies, bilaterally with the government, would establish the withdrawal order, with the condition that by 2040 at the latest all the coal in Chile would be withdrawn" [bn4]. There was a distinct perception during our interviews that this plan involved no subsidies for the Big Four, distinguishing it from Germany's coal policy. However, the plan does allow plants to enter a "Strategic Reserve State" (ERE) in which they receive capacity payments, for up to $60 \%$ of the value of their full capacity, for up to five years after retirement to remain operational in case of emergency [bn4, si1] (Bernal, 2020; Bnamericas, 2020a, 2020b; Gomez Agurto, 2019; Aprueba Acuerdos De Retiro De Centrales Termoelectricas a Carbon, 2020; Morawski, 2020).

Electricity generation companies in Chile were willing to quickly shift their position to coal generation for three reasons: first, they do not exclusively own coal assets; second, as multinational corporations, they have their own international climate goals; third, the Voluntary Coal Retirement Scheme may have mitigated risk in the sector. Regarding coal assets, after the passage of NCRE law, No. 20.257, the Big Four increased the percentage of renewable technologies in 
their portfolio. Currently, coal represents 15\% of Enel's generation capacity, 21\% of Colbún S.A.'s, $89 \%$ of AES Gener's and 58\% of Engie's assets in Chile. This demonstrates generators' lack of commitment to maintaining coal generation facilities that are no longer profitable or competitive with other generation sources. In other words, "these are electricity producers, they are not thermoelectric [companies] by definition" [bn4].

Instead, as three of the four are multinational corporations, their attitude toward decarbonization reflects "their own headquarters or their own countries of origin" [pn7]. These corporations, because of international pressure on climate change, have decarbonization strategies that their Chilean strategy must align with. As an example, in December 2019, Engie announced the early closure of two coal units in Mejillones. In the press release, Engie described itself as "a leader in zero-carbon transition" (ENGIE, 2019). While all of Chile's coal plants are owned by these four companies, these companies own power plants that use a range of energy sources, and their multinational nature coincides with international decarbonization strategies, mitigating their resistance to shifting from coal in Chile. Companies may also have entered these negotiations with the government in 2017 for a voluntary plan in order to avoid future legislation, which was seen as riskier [bn6].

Given the government's pro-business approach and the reticence of the Ministry of Energy to lead a top-down transition, there was alignment between the GoC and the private sector wherein all actors preferred an internally negotiated agreement on coal phase-out. Rather than wait for the outcome of a nonparticipatory legislative process, the Big Four were able to negotiate a phase-out that included a potential for a $60 \%$ capacity payment if plants remained in "strategic reserve status" in case of emergencies (Bnamericas, 2020a, 2020b; Morawski, 2020).

\section{Discussion and conclusions}

The GoC's Voluntary Coal Retirement Scheme was an unprecedented and bold policy in a sector whose initial design had precluded political interference. To understand the political forces driving Chile's decarbonization efforts, we have highlighted four main objectives: (1) affordable electricity prices, (2) energy security, (3) air quality and (4) decarbonization. The MoE's interest in affordability and energy security spurred changes in market design that enabled cheap renewables to compete with fossil fuel generation. This was made possible because of declining prices for solar, globally, as well as Chile's particularly high solar potential (Bloomberg NEF, 2020). Mobilization of civil society around air pollution also jeopardized the financial viability of coal projects. However, these were necessary, but not sufficient conditions for coal phase-out. Decarbonization policy was spurred by civil society, government and citizen interest in climate change, leading to the creation of the voluntary coal phase-out agreement, which compensated companies that own coal assets to retire their plants ahead of schedule. 
One key enabling factor that emerged in the narratives around decarbonization was Chile's technocratic approach to governance. Technocracy is usually defined by decision-making led by technical scientific experts. Because of this, political power "tends to gravitate towards technical elites," and science and technology become ways to legitimize decisions (Gunnell, 1982). In Chile, the government has traditionally relied on decision-making that is based on external sets of rules, criteria and models, especially in environmental policy (Barandiaran, 2016; Flores-Fernández, 2020; Simsek et al., 2019).

In particular, the Ministry of Energy has relied on models that demonstrate the technical feasibility of the energy transition, and the outputs of these models helped actors come into alignment around a set of assumptions. In other countries, increasing renewables in the energy mix raised concerns around flexibility and intermittency. However, in Chile, there is minimal pushback [bn2, bn4, pn8], since academic models and modelers in the Ministry of Energy have stated that it is technically possible to significantly increase renewable capacity and the electricity system has not yet reached the thresholds of what it can manage. Chile's technocratic orientation toward policymaking is reinforced by broad trust in these models, and support for an evidence-based, pragmatic and apolitical approach to decarbonization [bn3, bn4, pn5, pn6, pn7, si1, sn1, sn2, sn4, sn6].

However, during the second Bachelet administration (2014-2018), there was an increased emphasis on incorporating public participation into government decision-making, which has been at odds with Chile's technocratic approach. In Chile, public participation in decision-making has been framed as disruptive and unpredictable (Castiglioni \& Kaltwasser, 2016; Ureta, 2017). During the Bachelet II administration, increased calls for public input led to a redrafting of the 1980 constitution, although this new constitution was never ratified (Seminario \& Neaher, 2020). In the Ministry of Energy, under Maximo Pacheco, energy strategy was supposed to be "socially validated," and the new energy agenda of the Ministry called for "deeper dialogue" with communities impacted by energy projects (Ureta, 2017).

Given this recent participatory approach, we might expect a destabilization of Chile's reliance on technocratic policymaking, though the influence of public engagement in energy policy remains unclear. Environmental activists believed that public participation was a façade, and that few meaningful inputs from consulted parties were incorporated into policymaking [sn5, sn8]. This may be in part because of limits to public participation that are enshrined in the Chilean Constitution, which, as of 26 October 2020, will be redrafted by an elected, representative body. An oft-cited weakness of the current constitution, increasing public participation is a key goal among those who have called for a new constitution (Feng, 2020). The expectation from some actors has been that greater participation will increase the ambition of climate policy [pn5]. On the other hand, a competitive liberalized market, in tandem with a technocratic approach to policymaking, has avoided concentrating power in any particular energy company, which may have enabled the phase-out. 
Critics have called the 2040 deadline for coal plant closures unambitious, and even government actors voiced the opinion that NCRE energy laws are "very weak" and "not a strong policy" [pn5]. However, Chile's commitment to coal phase-out is a step toward decarbonizing the electricity sector and demonstrates progress toward its goal of carbon neutrality by 2050. In order to strengthen this agreement, legislation was brought before Congress in August 2020 that would enshrine coal phase-out into law and expedite the timeline to retire coal by 2025 . It would also initiate the immediate shutdown of power plants that have been in operation for more than 30 years (Bnamericas, 2020a). Even without new legislation, the coal phase-out has proceeded more quickly than promised, with Enel announcing that it would close its remaining coal plants by May 2022. At present, 17 coal-fired power plants are scheduled to operate until 2040.

In Chile's case, these steps have been made possible in great part by limited fossil fuels reserves, high renewable energy potential and exposure to international markets that make energy security a priority. These contextual factors set the stage for policies and reforms that supported inexpensive renewable energy development, which could compete with coal-fired power plants in Chile's electricity market. However, it was the rise of civil society actors in response to local air quality concerns and the increased relevance of climate change in Chile's national discourse that pushed government actors to develop an ambitious plan for coal phase-out in collaboration with energy companies. This alignment of actors and objectives facilitated action on decarbonization through coal phase-out in Chile, setting the nation on track to meet its international climate commitments.

\section{Appendix}

This chapter contains supplementary online material at www.mcc-berlin.net/ pecoal/ch04.

\section{References}

Agostini, C.A., Silva, C., \& Nasirov, S. (2017). Failure of energy mega-projects in Chile:A critical review from sustainability perspectives. Sustainability, 9(6), 1073. https://doi. org/10.3390/su9061073

Allain, M., \& Madariaga,A. (2020). Understanding policy change through bricolage:The case of Chile's renewable energy policy. Governance, 33(3), 675-692. https://doi.org/ $10.1111 /$ gove. 12453

Alvial-Palavicino, C., \& Opazo-Bunster, J. (2018). Looking back to go forward? The interplay between long-term futures and political expectations in sustainability transitions in Chile. Futures, 104, 61-74. https://doi.org/10.1016/j.futures. 2018.07.005

Ministry of Energy (2020) Exempt Decree. Aprueba Acuerdos De Retiro De Centrales Termoelectricas a Carbon, Pub. L. No. 50. https://energia.gob.cl/sites/default/files/ decreto_exento_n_50.pdf 
Azzopardi, T. (2018, November 29). Standoff Stalls Chilean Power Line That Has Just Miles to Go. Bloomberg Law. https://news.bloomberglaw.com/environment-and-energy/ standoff-stalls-chilean-power-line-that-has-just-miles-to-go

Barandiaran, J. (2016). The authority of rules in Chile's contentious environmental politics. Environmental Politics, 25(6), 1013-1033. https://doi.org/10.1080/ 09644016.2016.1218156

Bernal, N. G. (2020). Retiro de centrales a carbón: Incorporación del Estado de Reserva Estratégica en Chile (No. 127544). Biblioteca del Congreso Nacional de Chile. https://obtienearchivo.bcn.cl/obtienearchivo?id=repositorio/10221/29283/1/ BCN__Estado_de_Reserva_Estrate_gica_ERE_.pdf

Bersalli, G. (2019). Chile: An Emerging Key Actor in the Renewable Energy Arena (p. 20). Climate Chance. www.climate-chance.org/wp-content/uploads/2019/12/cp22019-energy-chile_en_20191204.pdf

Bloomberg NEF. (2020, April 28). Scale-up of Solar and Wind Puts Existing Coal, Gas at Risk. https://about.bnef.com/blog/scale-up-of-solar-and-wind-puts-existingcoal-gas-at-risk/

Bnamericas. (2019, October 23). Latin America electricity prices: How countries compare. Bnamericas. www.bnamericas.com/en/news/latin-america-electricityprices-how-countries-compare

Bnamericas. (2020a, August 25). Spotlight: Chilean congress pushes plan for accelerated coal retirement. Bnamericas. www.bnamericas.com/en/features/spotlight-chileancongress-pushes-plan-for-accelerated-coal-retirement

Bnamericas. (2020b, December 29). AES Gener pushing renewable strategy with new financing, projects. Bnamericas. www.bnamericas.com/en/news/aes-gener-pushingrenewable-strategy-with-new-financing-projects

Bustamante, J. M., Hurley, J. T., \& Ibarrola, D. (2016, August 9). Law 20,936: New power transmission systems and new independent coordinating body. Carey. www.carey.cl/ en/law-establishes-new-power-transmission-systems-and-creates-an-independentcoordinating-body-for-the-national-power-system-law-no-20-936/

Bustos-Salvagno,J. (2019). Chilean Experience on Long-term Electricity Auctions: Changes and Challenges Ahead. IAEE Energy Forum. www.iaee.org/en/publications/newsletterdl. aspx?id=816

Carrasco, S., \& Maillet, A. (2019). 30 años de institucionalidad ambiental en Chile: Entre la esperanza y las promesas incumplidas (1990-2018). In Chile y el cambio climático: Pensar globalmente, actuar localmente. Friedrich-Ebert-Stiftung. http://library. fes.de/pdf-files/bueros/mexiko/15672.pdf

Castiglioni, R., \& Kaltwasser, C. R. (2016). Challenges to political representation in contemporary Chile. Journal of Politics in Latin America, 8(3), 3-24. https://doi.org/ 10.1177/1866802X1600800301

Chávez-Rodríguez, M.,Varela, D., Rodrigues, F., Salvagno, J. B., Köberle, A. C., VasquezArroyo, E., Raineri, R., \& Rabinovich, G. (2017). The role of LNG and unconventional gas in the future natural gas markets of Argentina and Chile. Journal of Natural Gas Science and Engineering, 45, 584-598. https://doi.org/10.1016/ j.jngse.2017.06.014

CNE. (2020, November 30). Evolución de la Generación Bruta en Chile. Energía Abierta. http://energiaabierta.cl/visualizaciones/evolucion-generacion-bruta/

Constitution of the Republic of Chile. (1980). http://confinder.richmond.edu/admin/ docs/Chile.pdf 
Cordero Vega, L. (2010, August). What is Barrancones teaching us?. CIPER Chile. https://ciperchile.cl/2010/08/26/\%c2\%bfque-nos-esta-ensenando-barrancones/

Díaz-Robles, L., Saavedra, H., Schiappacasse, L., \& Cereceda-Balic, F. (2011). The air quality in Chile: Twenty years of challenge. Environmental Management (EM), Air $\mathcal{E}$ Waste Management Association, 3, 28-33. http://pubs.awma.org/gsearch/em/2011/ 8/diaz-robles.pdf

EIA. (2021). Chile Data. EIA Independent Statistics and Analysis. www.eia.gov/international/data/country/CHL

Ellis, J., Castilhos Rypl, N., Callens, J., Kimmel, M., \& Zindler, E. (2019). Chile Power System Outlook. BloombergNEF. https://data.bloomberglp.com/professional/sites/ 24/Flexibility-Solutions-for-High-Renewable-Energy-Systems-Chile-Outlook.pdf

Enerdata. (2020). Share of Wind and Solar in Electricity Production. https://yearbook. enerdata.net/renewables/wind-solar-share-electricity-production.html

ENGIE. (2019, December 10). ENGIE to Replace 1 GW of Coal Assets with $1 \mathrm{GW}$ of Renewables. www.engie.com/en/press-releases/replace-1-gw-coal-assets-with-1gw-renewables

Feng, D. (2020, November 27). What can Chile teach us about democracies and constitutions?. The Globe Post. https://theglobepost.com/2020/11/27/chileconstitution-reform-interview/

Flores-Fernández, C. (2020). The Chilean energy "transition": Between successful policy and the assimilation of a post-political energy condition. Innovation: The European Journal of Social Science Research, 33(2), 173-193. https://doi.org/10.1080/ 13511610.2020.1749836

Friedman, M. (1992). The Drug War as a Socialist Enterprise. Friedman \& Szasz on Liberty and Drugs.

Furnaro, A. (2019). Neoliberal energy transitions: The renewable energy boom in the Chilean mining economy. Environment and Planning E: Nature and Space. 3(4), 951975. https://doi.org/10.1177/2514848619874685

Global Petrol Prices. (2021, April 10). Chile Electricity Prices. www.globalpetrolprices. com/Chile/electricity_prices/

GoC. (2020). Chile's NDC - 2020 Update. www4.unfccc.int/sites/ndcstaging/ PublishedDocuments/Chile\%20First/Chile\%27s_NDC_2020_english.pdf

Gomez Agurto, C. (2019, May). The Energy Transition of Phasing out and/or technology reconversion of Coal Power Generation. Sustainable Energy Transition Initiative Conference, Santiago, Chile.

Greenpeace. (2019, July 30). Greenpeace Illuminates Polluting Coal Plant with Giant Digital Projections, Calls for Its Immediate Closure. Greenpeace. www.greenpeace.org/chile/ noticia/issues/climayenergia/greenpeace-illuminates-polluting-coal-plant-withgiant-digital-projections-calls-for-its-immediate-closure/

Greenpeace. (2021). Pide el cierre de las termoeléctricas de Quintero-Puchuncaví. Greenpeace. www.greenpeace.org/chile/involucrate/chao-carbon/

Gunnell, J. G. (1982). The technocratic image and the theory of technocracy. Technology and Culture, 23(3), 392. https://doi.org/10.2307/3104485

IEA. (2018). Energy Policies Beyond IEA Countries: Chile. IEA. https://doi-org.proxy.lib. duke.edu/10.1787/9789264290242-en

Jakob, M., Flachsland, C., Steckel, J. C., \& Urpelainen, J. (2020). Actors, objectives, context: A framework of the political economy of energy and climate policy applied to India, Indonesia, and Vietnam. Energy Research \& Social Science, 70, 101775. 
Linazasoro Espinoza, I. (2020). La buena administración como regla de adaptabilidad en un contexto de cambio climático. Revista de Derecho Ambiental, 13, 145-162. https:// doi.org/10.5354/0719-4633.2020.54169

Lizama, H., \& Figueroa Serrano, N. (2018). Calidad del Aire: Cuarto Reporte del Estado del Medio Ambiente. Ministra del Medio Ambiente. https://sinia.mma.gob.cl/wp-content/uploads/2019/01/Cuarto-reporte-del-medio-ambiente-compressed.pdf

Madariaga, A. (2019). From 'green laggard' to regional leader: Explaining the recent development of environmental policy in Chile. Bulletin of Latin American Research, 38(4), 453-470. https://doi.org/10.1111/blar.12841

Madariaga, A., \& Allain, M. (2018). Contingent coalitions in environmental policymaking: How civil society organizations influenced the Chilean renewable energy boom. Policy Studies Journal, 48(3), 672-699. https://doi.org/10.1111/psj.12298

Mardones, C., \& Flores, B. (2017). Evaluation of a $\mathrm{CO}_{2}$ tax in Chile: Emissions reduction or design problems?. Latin American Research Review, 52(3), 334-343.

Ministry of Environment. (2018, February). Resultados encuesta nacional de medioambiente 2018. https://mma.gob.cl/wp-content/uploads/2018/02/Primeros-ResultadosEncuesta-Nacional-de-Medioambiente-2018.pdf

MoE. (2016). Energy 2050: Chile's Energy Policy. Ministry of Energy. www.energia2050. cl/wp-content/uploads/2016/08/Energy-2050-Chile-s-Energy-Policy.pdf

Morawski, B. R. (2020, December 30). AES Chilean Subsidiary Accelerates Retirement of 322-MW of Coal Units. S\&P Global. www.spglobal.com/marketintelligence/ en/news-insights/latest-news-headlines/aes-chilean-subsidiary-acceleratesretirement-of-322-mw-of-coal-units-61926727

Murillo, M.V., \& Foulon, C. L. (2006). Crisis and policymaking in Latin America:The case of Chile's 1998-99 electricity crisis. World Development, 34(9), 1580-1596.

Nasirov, S., O'Ryan, R., \& Osorio, H. (2020). Decarbonization tradeoffs: A dynamic general equilibrium modeling analysis for the Chilean power sector. Sustainability, MDPI, 12(19), 8248. https://doi.org/doi:10.3390/su12198248

Pacheco, M. (2018). Revolución Energética en Chile. Ediciones UDP.

Pew Research. (2015, June 23). Spring 2015 Global Attitudes Survey. Pew Research Center's Global Attitudes Project. www.pewresearch.org/global/2015/06/23/ spring-2015-survey/

PPCA. (n.d.). Powering Past Coal Alliance. https://poweringpastcoal.org/

Reuters. (2012, August 28). Chile Top Court Rejects $\$ 5$ bln Castilla Power Project. Reuters. www.reuters.com/article/chile-castilla-idINL2E8JS82620120828

Reuters. (2015, January 29). Endesa Chile Suspends Punta Alcalde Power Project. Reuters. www.reuters.com/article/endesa-chile-power-puntaalcalde-idAFL1N0V82UX 20150129

Rogelj, J., Shindell, D., Jiang, K., Fifita, S., Forster, P., Ginzburg,V., Handa, C., Kobayashi, S., Kriegler, E., Mundaca, L., Séférian, R., Vilariño, M. V., Calvin, K., Emmerling, J., Fuss, S., Gillett, N., He, C., Hertwich, E., Höglund-Isaksson, L., ... Schaeffer, R. (2018). SR15: Mitigation Pathways Compatible with $1.5^{\circ} \mathrm{C}$ in the Context of Sustainable Development (p. 82). IPCC. www.ipcc.ch/site/assets/uploads/sites/2/2019/02/ SR15_Chapter2_Low_Res.pdf

Seminario, M. R., \& Neaher, G. (2020, October 5). The 2020 Chilean Plebiscite: Overview, Citizen Engagement, and Potential Impact. Center for Strategic \& International Studies. www.csis.org/analysis/2020-chilean-plebiscite-overview-citizen-engagementand-potential-impact 
Simsek,Y., Lorca,Á., Urmee,T., Bahri, P.A., \& Escobar, R. (2019). Review and assessment of energy policy developments in Chile. Energy Policy, 127, 87-101. https://doi.org/ 10.1016/j.enpol.2018.11.058

Solimano, A. (2012). Chile and the neoliberal trap: The Post-Pinochet era. Cambridge University Press. 1-167. 10.1017/CBO9781139035071.

Stern, L. (1999). Market distortions in the Chilean electric generation sector-ProQuest. Journal of Project Finance, 5(3), 41-52.

Tapia-Gatica, J., González-Miranda, I., Salgado, E., Bravo, M.A., Tessini, C., Dovletyarova, E. A., Paltseva, A. A., \& Neaman, A. (2020). Advanced determination of the spatial gradient of human health risk and ecological risk from exposure to $\mathrm{As}, \mathrm{Cu}, \mathrm{Pb}$, and $\mathrm{Zn}$ in soils near the Ventanas Industrial Complex (Puchuncaví, Chile). Environmental Pollution, 258, 113488. https://doi.org/10.1016/j.envpol.2019.113488

Tecklin, D., Bauer, C., \& Prieto, M. (2011). Making environmental law for the market: The emergence, character, and implications of Chile's environmental regime. Environmental Politics, 20(6), 879-898. https://doi.org/10.1080/ 09644016.2011 .617172

Timilsina, G. R. (2020). Demystifying the Costs of Electricity Generation Technologies (No. 9303; Policy Research Working Paper). World Bank. https://openknowledge. worldbank.org/bitstream/handle/10986/34018/Demystifying-the-Costs-ofElectricity-Generation-Technologies.pdf?sequence $=4 \&$ isAllowed $=\mathrm{y}$

Tringas, T. (2011,April). Chile Levelised Cost of Energy. Bloomberg New Energy Finance. www.nrdc.org/sites/default/files/ene_11052401a.pdf

Ureta, S. (2017). A very public mess: Problematizing the "participative turn" in energy policy in Chile. Energy Research \& Social Science, 29, 127-134. https://doi.org/ 10.1016/j.erss.2017.04.009

Villalobos, C., Chávez, C., \& Uribe, A. (2021). Energy poverty measures and the identification of the energy poor: A comparison between the utilitarian and capabilitybased approaches in Chile. Energy Policy, 152, 112146. https://doi.org/10.1016/ j.enpol.2021.112146 